\title{
Foraging activity and demographic patterns of two termite species (Isoptera: Rhinotermitidae) living in urban landscapes in southeastern Brazil
}

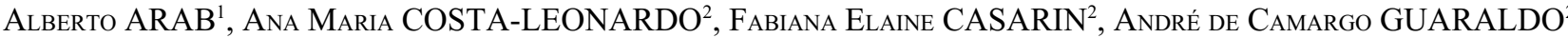 \\ and RICARDO C. CHAVES ${ }^{2}$ \\ ${ }^{1}$ Universidade de São Paulo (USP), Escola Superior de Agricultura “Luiz de Queiroz" (Esalq), Departamento de Entomologia, \\ Fitopatologia e Zoologia Agrícola, Piracicaba - SP, CEP 13418-900, Brazil; e-mail: alberto@esalq.usp.br \\ ${ }^{2}$ Universidade Estadual Paulista (UNESP), Instituto de Biociências, Departamento de Biologia, Rio Claro - SP, CEP 13506-900, \\ Brazil
}

Key words. Isoptera, Rhinotermitidae, subterranean termites, mark-release-recapture, territory size, wood consumption

\begin{abstract}
Coptotermes gestroi and Heterotermes tenuis (Isoptera: Rhinotermitidae) are important pests in southeastern Brazil causing serious economic damage. In this study we determined the demographic patterns and foraging activity of these species using mark-release-recapture and the consumption of wooden stakes. Using both the weighted mean and Lincoln index methods, population estimates ranged from $\approx 0.57$ to 1.99 million individuals for $C$. gestroi and from $\approx 0.20$ to 1.37 million for $H$. tenuis. Territory size of the colonies ranged from 172.5 to $5235 \mathrm{~m}^{2}$ for C. gestroi and from 16 to $40 \mathrm{~m}^{2}$ for H. tenuis. Our results also indicate that foraging activity was dependent on the minimum temperature; however, the existence of a compensation strategy in the foraging activities may permit foragers to exploit food sources under different environmental conditions.
\end{abstract}

\section{INTRODUCTION}

Subterranean termites (Rhinotermitidae) are known to form large colonies that may contain thousands of individuals. The colonies of these termites are composed of workers, soldiers, nymphs, and both primary and secondary reproductives. The workers are the more abundant caste and are responsible for most colony tasks including foraging, construction and repair of the nest, larvae and soldier feeding, and colony defense. Demographic parameters of termite colonies have been estimated by different methods including direct counting of the entire population, exhaustive trapping, and mark-releaserecapture. Direct counting of the individuals of an entire colony has been used to determine population size in mound and tree-nesting species (Nutting \& Jones, 1990). However, colonies of subterranean termites are generally located some distance from food sources (Evans et al., 1999). Furthermore, some species of subterranean termites form satellite nests and, thus, estimating their colony size by this method is difficult.

A colony of subterranean termites can simultaneously exploit several food sources, which are connected with the nest by a complex of tunnels and galleries. Consequently, the foraging population can provide a good estimate of colony size and territory range. Mark-release-recapture methods are currently used to estimate the size of the foraging population of subterranean termites (Su \& Scheffrahn, 1988; Grace et al., 1989; Jones, 1990; Nutting \& Jones, 1990; Haagsma \& Rust, 1995). These methods make certain assumptions, which according to Evans et al. (1999) are frequently violated in studies of both tropical and temperate termites, and result in overestimates of population size (Forschler \& Townsend, 1996; Evans et al., 1998).
Wood consumption by termites is influenced by both intrinsic and extrinsic factors, such as competition with other organisms, population size of the colony, food availability, and environmental conditions. Laboratory studies of wood consumption in termites reveal that termites are selective feeders and show a preference for certain types of wood (Waller \& La Fage, 1987; Delaplane \& La Fage, 1989). However, it is not clear whether the results observed in these studies are mediated by volume and position of the wood, environmental conditions and/or interaction with other organisms. Wood stakes are currently used for monitoring termite colonies in both prevention and control programs of subterranean termites (Su \& Scheffrahn, 1996, 1998). Indeed, metabolic inhibitors, chitin inhibitors and juvenoids are sometimes applied to wooden stakes buried in areas infested with subterranean termites ( $\mathrm{Su} \&$ Scheffrahn, 1998; Lee, 2002).

The subterranean termites Coptotermes gestroi Wasmann 1896 (formerly known as C. havilandi, see Kirton \& Brown, 2003) and Heterotermes tenuis Hagen, 1858 (Rhinotermitidae) are pests of great economic importance in urban areas of southeastern Brazil. The Asian subterranean termite $C$. gestroi was accidentally introduced into the southeast region of Brazil in a marine cargo, probably at the beginning of the $20^{\text {th }}$ century (Araujo, 1958). This species has rapidly colonized areas throughout southern Brazil, with increasing economic impact. H. tenuis is a native species that damages agricultural crops such as sugarcane and wooden structures in urban areas. In some urban sites, these species are sympatric, often with overlapping foraging territories. The aims of this study were to estimate the foraging population and territory size of $C$. gestroi and $H$. tenuis colonies and determine the foraging 
activity of these species by measuring the consumption of wooden stakes. Such information will increase our understanding of the foraging behaviour and food preferences of these species, with the objective of developing a better pest management strategy.

\section{MATERIAL AND METHODS}

\section{Study site and species}

Two colonies of Coptotermes gestroi $(\mathrm{C} 1$ and $\mathrm{C} 2)$ and Heterotermes tenuis ( $\mathrm{H} 1$ and $\mathrm{H} 2)$ were used in this study. The colonies were located in Rio Claro city, SP, Brazil $\left(22^{\circ} 23^{\prime} \mathrm{S}\right.$, $47^{\circ} 31^{\prime} \mathrm{W}$ ). Extensive damage caused by C. gestroi is recognized by the distinct foraging tubes in wooden structures ( $\mathrm{Su}$ et al., 2000). Colony $C 1$ were located in a residential area in Rio Claro city $(\mathrm{C} 1)$, whereas colony $(\mathrm{C} 2)$ was located close to the Center for the Study of Social Insects (CEIS) at UNESP. Colony C2 was located $5 \mathrm{~km}$ from colony $\mathrm{C} 1$. On the other hand, colonies $\mathrm{H} 1$ and $\mathrm{H} 2$ were attacking the trunks of dead Eucalyptus sp. trees in the garden of the UNESP in Rio Claro city. The foraging territory of $\mathrm{H} 1$ was located $500 \mathrm{~m}$ from that of $\mathrm{H} 2$. Furthermore, colonies $\mathrm{H} 1$ and $\mathrm{H} 2$ were considered to be independent as the individuals of these colonies showed strong agonistic behaviour to one another (Fig. 1).

\section{Mark-release-recapture}

A triple mark-release-recapture was used to estimate the size of the foraging population and territory range of the colonies of these species. The colonies were monitored for two months by checking weekly rolls of tissue buried in the ground. Once termite activity was confirmed, the tissue rolls were replaced by cardboard traps (monitoring stations) before the first marking. For $H$. tenuis colonies, new monitoring stations were established in a concentric position around the old ones in a $2 \times 2 \mathrm{~m}$ grid. For $C$. gestroi colonies, the monitoring stations were placed around the buildings at intervals of $2 \mathrm{~m}$ (Fig. 1).

The mark-recapture was conducted during April and May 2001. Termites collected from the monitoring stations with the highest number of individuals were separated from the cardboard and confined in $10 \mathrm{~cm}$ Petri dishes. Ten reference samples of 10 workers were taken from each colony to determine individual weight. Body weight (mean $\pm \mathrm{SE}$ ) of an individual worker of colony $\mathrm{C} 1$ was $3.10 \pm 0.10 \mathrm{mg}$ and for $\mathrm{C} 2$ was $3.48 \pm$ $0.10 \mathrm{mg}$. On the other hand, the body weight (mean $\pm \mathrm{SE}$ ) of workers of colonies $\mathrm{H} 1$ and $\mathrm{H} 2$ was $2.40 \pm 0.10 \mathrm{mg}$. The termites were marked by feeding them for one week on filter paper impregnated with a $0.05 \%$ (weight/volume) solution of Nile blue dye. In preliminary experiments, workers of both species showed a uniform dark blue colour after the marking process, which was continued for 40 days. The mean $( \pm$ SE) percentage survival of workers during the marking process was $98.5 \pm 0.5 \%$ for $C$. gestroi and $98 \pm 1 \%$ for $H$. tenuis. In order to avoid the possibility of the transfer of marks only dark blue coloured individuals were used for the population estimates. Mark transfer by cannibalism is reported in some termite species (Evans et al., 1998, 1999), including C. gestroi and H. tenuis (Costa-Leonardo, unpubl.), and individuals that acquire marks in this way are a lighter colour than those that fed directly on the dye.

Marked termites were weighed and released at the station where they were collected. All the monitoring stations were used for mark/recapture events and termites were collected one week later. Unmarked termites collected at the monitoring stations were weighed, stained and released. Termites were marked, released, and recaptured three times over a period of 42 days. The population estimate was calculated using the Lincoln index and weighted mean method. The Lincoln index is the sim- plest estimator of population size using marked individuals, involving just one release and one recapture. On the other hand, the weighted mean utilizes data collected on several days. Both methods make the same assumptions (Begon, 1979). The mean foraging population and standard error were calculated averaging the three Lincoln index estimates. Only those recaptured workers that were darkly marked were considered marked in this study. The foraging territory of the colonies of $C$. gestroi and $H$. tenuis, defined as the area encompassed by the monitoring stations, was determined by the presence of marked termites. Maximum linear foraging distance was defined as the linear distance between the outermost monitoring stations at which marked individuals were found.

Behavioural assumptions of mark-recapture were tested before determining the foraging patterns of the two species (Begon, 1979; Thorne et al., 1996; Evans et al., 1998). The assumption of complete mixing of both marked and unmarked individuals was tested by comparing the proportion of marked individuals at each monitoring station. If mixing was uniform, the number of marked individuals should increase at each subsequent recapture. Pearson correlations between the number of marked individuals and the total number of recaptured individuals were calculated. Additionally, if foraging individuals move randomly between feeding sites, an equal proportion of marked individuals would be found at all monitoring stations. Therefore, a $\chi^{2}$-test was used to test if the number of marked individuals varied among the monitoring stations at a particular recapture event (Sokal \& Rohlf, 1995).

\section{Foraging activity}

Foraging activity of $C$. gestroi and $H$. tenuis was determined by the consumption of wooden stakes placed in the foraging territories of four colonies of each species. This experiment was conducted during the summer (December-March) and winter seasons (June-August). Ten Pinus sp. and Eucalyptus sp. stakes of two sizes $(28 \mathrm{~cm} \times 6 \mathrm{~cm} \times 4 \mathrm{~cm} ; 28 \mathrm{~cm} \times 2 \mathrm{~cm} \times 2 \mathrm{~cm})$ were used in each colony. Dry weight was estimated by oven-drying the stakes at $120^{\circ} \mathrm{C}$ for $12 \mathrm{~h}$. Afterwards, the stakes were buried $23 \mathrm{~cm}$ deep in the foraging territories of the termites in $4 \times 4 \mathrm{~m}$ grids. All the stakes were collected after a three-month exposure to termite attack and oven-dried at $120^{\circ} \mathrm{C}$ for $12 \mathrm{~h}$. Wood consumption was the difference in the dry weight before and after the experiment. The results of wood consumption were subjected to logarithmic transformation in order to improve the normality and homogeneity of the variance (Sokal \& Rohlf, 1995).

An ANOVA was used to analyze mean differences in wood consumption, in terms of maximum depth and minimum depth of the attack, and the effects of the size of stakes and type of wood. Significant differences were separated using a Tukey HSD test $(\mathrm{p}<0.05)$. The percentage of the wooden stakes attacked was correlated with average precipitation and minimum and maximum temperatures $(\mathrm{p}<0.05)$ in order to determine if climatic variables affected foraging activity.

\section{RESULTS}

\section{Mark-release-recapture}

The number of marked termites released, number of termites captured, and number of marked termites among those recaptured during the triple mark-release-recapture are summarized in Table 1. In the colonies of both species, the mean percentage $( \pm \mathrm{SE})$ of marked individuals recaptured was $1.27 \pm 0.37 \%$ for $C$. gestroi and $1.69 \pm 1.1 \%$ for H. tenuis. Marked workers of $C$. gestroi were recovered from monitoring stations encompassing 


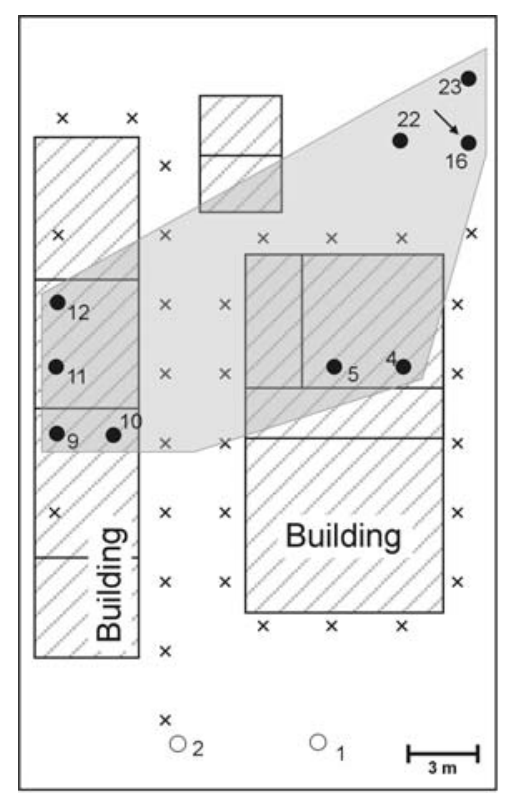

C1

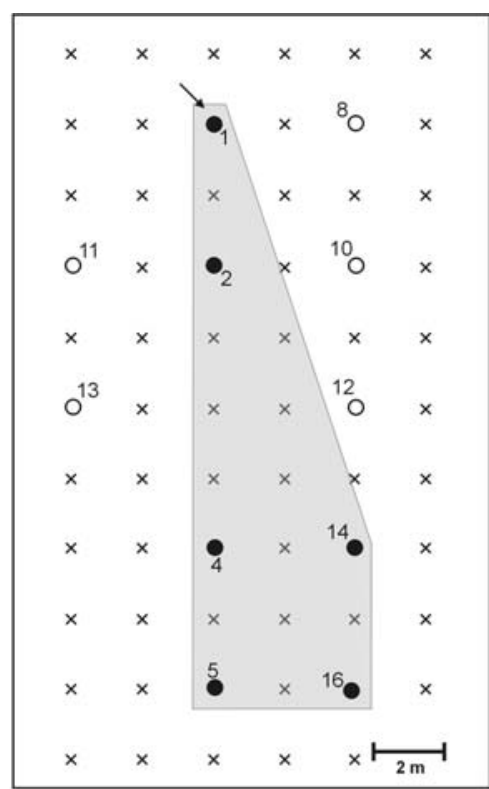

$\mathrm{H} 1$

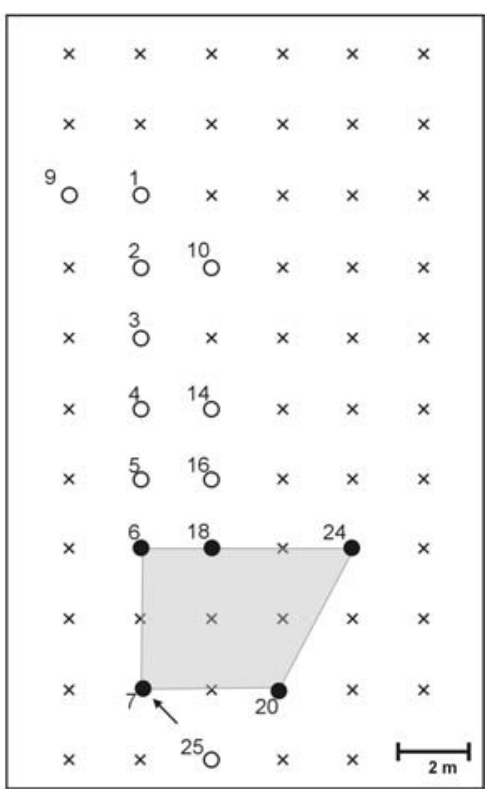

$\mathrm{H} 2$

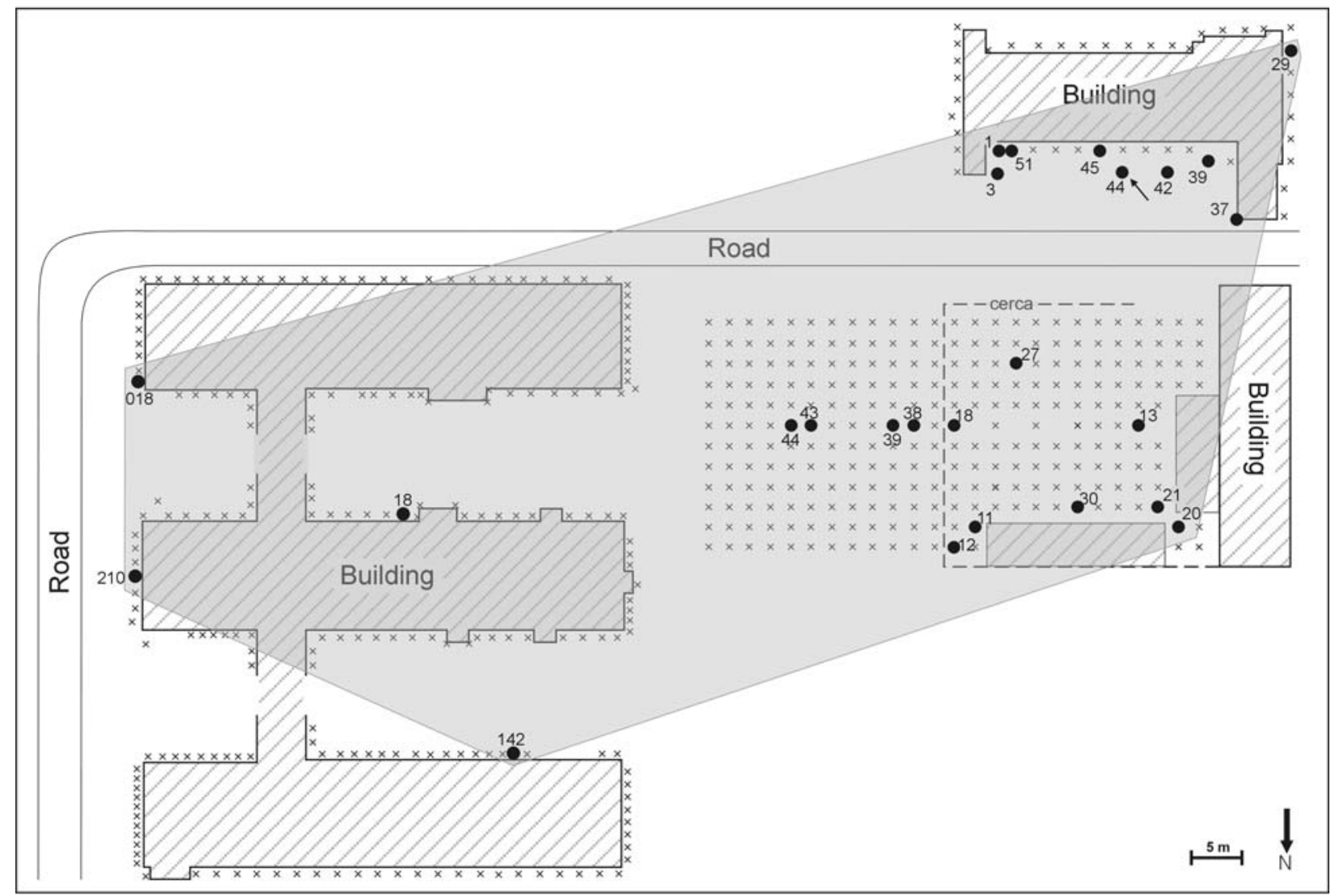

C2

Fig. 1. Territories foraged (shaded areas) by $\mathrm{C} 1$ and $\mathrm{C} 2$ colonies of C. gestroi and $\mathrm{H} 1$ and $\mathrm{H} 2$ of H. tenuis. X denotes position of an underground trap; solid circles (with identification numbers) denote monitoring stations with marked termites; open circles (with identification numbers) denote monitoring stations with unmarked termites; arrows indicate the monitoring stations at which the marked termites were initially released.

areas of approximately $172-5200 \mathrm{~m}^{2}$ and for $H$. tenuis of $16-40 \mathrm{~m}^{2}$ (Fig. 1, Table 1).

The Lincoln index estimates of $C$. gestroi colonies ranged from $\approx 0.57$ to 1.81 million workers, while the weighted mean estimates ranged from $\approx 0.65$ to 1.99 million workers and of $H$. tenuis colonies, from $\approx 0.20$ to 0.93 and $\approx 0.28$ to 1.37 , respectively (Table 2 ). Workers of $C$. gestroi travelled a maximum distance of approxi- 
TABLE 1. Number of marked termites released (ri), number of termites captured (ni), number of marked termites among those recaptured (mi) and estimated territory size (ti) obtained by the triple mark-release-recapture method.

\begin{tabular}{|c|c|c|c|c|c|c|c|c|c|c|c|c|}
\hline \multirow{3}{*}{ Colony } & \multicolumn{12}{|c|}{ Recapture cycle } \\
\hline & \multicolumn{4}{|c|}{ I } & \multicolumn{4}{|c|}{ II } & \multicolumn{4}{|c|}{ III } \\
\hline & ri & ni & $\mathrm{mi}$ & $\mathrm{ti}\left(\mathrm{m}^{2}\right)$ & ri & ni & $\mathrm{mi}$ & $\mathrm{ti}\left(\mathrm{m}^{2}\right)$ & ri & ni & $\mathrm{mi}$ & $\mathrm{ti}\left(\mathrm{m}^{2}\right)$ \\
\hline $\mathrm{C} 1$ & 11659 & 8214 & 30 & 114.8 & 19873 & 11313 & 171 & 114.8 & 31186 & 10865 & 365 & 172.5 \\
\hline $\mathrm{C} 2$ & 5625 & 5819 & 194 & 256 & 11750 & 11820 & 70 & 3496 & 3093 & 3976 & 73 & 5235 \\
\hline H1 & 2601 & 6686 & 103 & 40 & 9287 & 5284 & 395 & 40 & 14571 & 5092 & 240 & 40 \\
\hline $\mathrm{H} 2$ & 4331 & 5289 & 22 & 4 & 10320 & 4977 & 77 & 12 & 15297 & 4925 & 79 & 20 \\
\hline
\end{tabular}

mately 24 to $133 \mathrm{~m}$ between the outermost foraging stations and for $H$. tenuis it was 7 to $16 \mathrm{~m}$ (Table 2). Live weight of the foraging populations of $C$. gestroi ranged from 2.27 to $6.35 \mathrm{~kg}$ and from 0.68 to $3.29 \mathrm{~kg}$ for $H$. tenuis.

Workers of both species did not mix uniformly within the foraging territories. For two colonies, there was no significant increase in the number of marked individuals against the total number of individuals recaptured at the monitoring stations $(C$. gestroi: $\mathrm{r}=0.2857 ; \mathrm{p}=0.583)(H$. tenuis: $\mathrm{r}=-0.2636 ; \mathrm{p}=0.614)$. Moreover, the proportion of marked individuals was not homogeneous in the foraging territories of the colonies of C. gestroi $\left(\mathrm{C} 1: \chi^{2}=\right.$ 494.24, $\mathrm{df}=8, \mathrm{p}<0.0001 ; \mathrm{C} 2: \chi^{2}=289.52, \mathrm{df}=13, \mathrm{p}<$ $0.0001)$ and H. tenuis $\left(\mathrm{H} 1: \chi^{2}=584.89\right.$, $\mathrm{df}=5, \mathrm{p}<$ 0.0001; $\left.\mathrm{H} 2: \chi^{2}=41.73, \mathrm{df}=3, \mathrm{p}<0.0001\right)$.

\section{Foraging activity}

Foraging activity of $C$. gestroi and $H$. tenuis colonies (measured by the number of stakes attacked by termites) appeared to be dependent on temperature. On average, a greater percentage of the wooden stakes were attacked in summer (24.24\%) than in winter (9.52\%). Analysis of the percentage of stakes attacked and environmental factors (Fig. 2) indicated that minimum temperature was significantly related to the number of stakes attacked both in summer and winter $\left(\mathrm{R}^{2}=0.878, \mathrm{~F}_{(1,10)}=28.81, \mathrm{p}=0.006\right.$, $\mathrm{N}=12$ ). Maximum temperature and precipitation did not influence the foraging activity of either species of termite (Maximum temperature: $\mathrm{R}^{2}=0.641 ; \mathrm{F}_{(1,10)}=7.15 ; \mathrm{p}=$ $0.056, \mathrm{~N}=12$. Precipitation: $\mathrm{R}^{2}=0.086 ; \mathrm{F}_{(1,10)}=5.16 ; \mathrm{p}=$ $0.056, \mathrm{~N}=12$ ).

TABLE 2. Estimates of the foraging populations and maximum linear foraging distance of $C$. gestroi and H. tenuis, living in colonies located in urban areas.

\begin{tabular}{|c|c|c|c|}
\hline Colony & $\begin{array}{c}\text { Estimator } \\
\text { method }\end{array}$ & $\begin{array}{l}\text { Population } \\
( \pm \mathrm{SE})\end{array}$ & $\begin{array}{c}\text { Linear } \\
\text { Distance (m) }\end{array}$ \\
\hline \multirow{2}{*}{$\mathrm{C} 1$} & Weighted mean & $1995427 \pm 68923$ & \multirow{2}{*}{23.57} \\
\hline & Lincoln Index & $1811768 \pm 230426$ & \\
\hline \multirow{2}{*}{$\mathrm{C} 2$} & Weighted mean & $655127 \pm 35740$ & \multirow{2}{*}{133.33} \\
\hline & Lincoln Index & $571194 \pm 38560$ & \\
\hline \multirow{2}{*}{$\mathrm{H} 1$} & Weighted mean & $286678 \pm 10559$ & \multirow{2}{*}{16} \\
\hline & Lincoln Index & $200739 \pm 13832$ & \\
\hline \multirow{2}{*}{$\mathrm{H} 2$} & Weighted mean & $1372923 \pm 103198$ & \multirow{2}{*}{7.14} \\
\hline & Lincoln Index & $933235 \pm 135706$ & \\
\hline
\end{tabular}

The total mean consumption of the two termite species, observed over a 3-month period, did not differ significantly $\left(\mathrm{F}_{(1,21)}=3.55, \mathrm{df}=1, \mathrm{p}=0.073, \mathrm{~N}=24\right)$. The wood consumption was $32.99 \pm 16.41 \mathrm{~g}$ for $C$. gestroi and $18.02 \pm 4.51 \mathrm{~g}$ for $H$. tenuis. Non-significant differences were also found in total consumption in the two seasons $\left(\mathrm{F}_{(1,21)}=2.95, \mathrm{df}=1, \mathrm{p}=0.101, \mathrm{~N}=24\right)$. Conversely, there were significant differences in the type of wood $\left(\mathrm{F}_{(1,21)}=24.96, \mathrm{df}=1, \mathrm{p}<0.0001, \mathrm{~N}=24\right)$ and size of the stakes consumed $\left(\mathrm{F}_{(1,21)}=27.43, \mathrm{df}=1, \mathrm{p}<0.0001, \mathrm{~N}=\right.$ 24). The mean consumption of Pinus sp. $(26.76 \pm 6.86 \mathrm{~g})$ was significantly greater $(\mathrm{p}=0.001$; Tukey HSD test) than of Eucalyptus sp. stakes $(5.76 \pm 2.50 \mathrm{~g})$. Furthermore, termites of both species significantly consumed more of the large $(33.71 \pm 9.36 \mathrm{~g})$ than the small stakes $(9.00 \pm 2.42 \mathrm{~g})(\mathrm{p}=0.0002$; Tukey HSD test $)$.

Maximum mean depth of attack did not differ significantly between termite species $\left(\mathrm{F}_{(1,21)}=1.64, \mathrm{df}=1\right.$, $\mathrm{p}=0.214, \mathrm{~N} 24)$. The maximum mean depth of attack was $24.86 \pm 2.30 \mathrm{~cm}$ for $C$. gestroi and $27.53 \pm 0.36 \mathrm{~cm}$ for $H$. tenuis. Non-significant differences were found in the maximum mean depth between seasons $\left(\mathrm{F}_{(1,21)}=\right.$ 0.275 , df $=1, \mathrm{p}=0.605, \mathrm{~N}=24)$. The maximum mean depth of the attack in summer was $26.13 \pm 1.07 \mathrm{~cm}$ and $28.00 \pm 0.00 \mathrm{~cm}$ in winter. Moreover, minimum mean depth of attack was similar for both termite species $\left(\mathrm{F}_{(1,21)}\right.$ $=0.10, \mathrm{df}=1, \mathrm{p}=0.751, \mathrm{~N}=24)$. The minimum mean depth of attack was $7.71 \pm 2.74 \mathrm{~cm}$ for $C$. gestroi and $8.29 \pm 1.10 \mathrm{~cm}$ for $H$. tenuis. There were no significant differences in the minimum mean depth of attack between the two seasons $\left(\mathrm{F}_{(1,21)}=0.06, \mathrm{df}=1, \mathrm{p}=0.804, \mathrm{~N}=24\right)$. The minimum mean depth of the attack was $8.22 \pm 1.54$ $\mathrm{cm}$ in summer and $7.94 \pm 1.18 \mathrm{~cm}$ in winter.

\section{DISCUSSION}

Table 3 summarizes the published estimates of the size of the foraging populations of colonies of some species of subterranean termites obtained using the Lincoln index and weighted mean methods. There are differences in the population sizes, territory sizes, and maximum linear distance travelled by the workers of the different termite species. The range of colony sizes recorded for some species may indicate a range of age classes affected by environmental conditions, competition with other termites, colony health and the number of monitoring stations, or the method used to estimate the size of the foraging population (Waller \& La Fage, 1987; Lenz, 1994). The popu- 

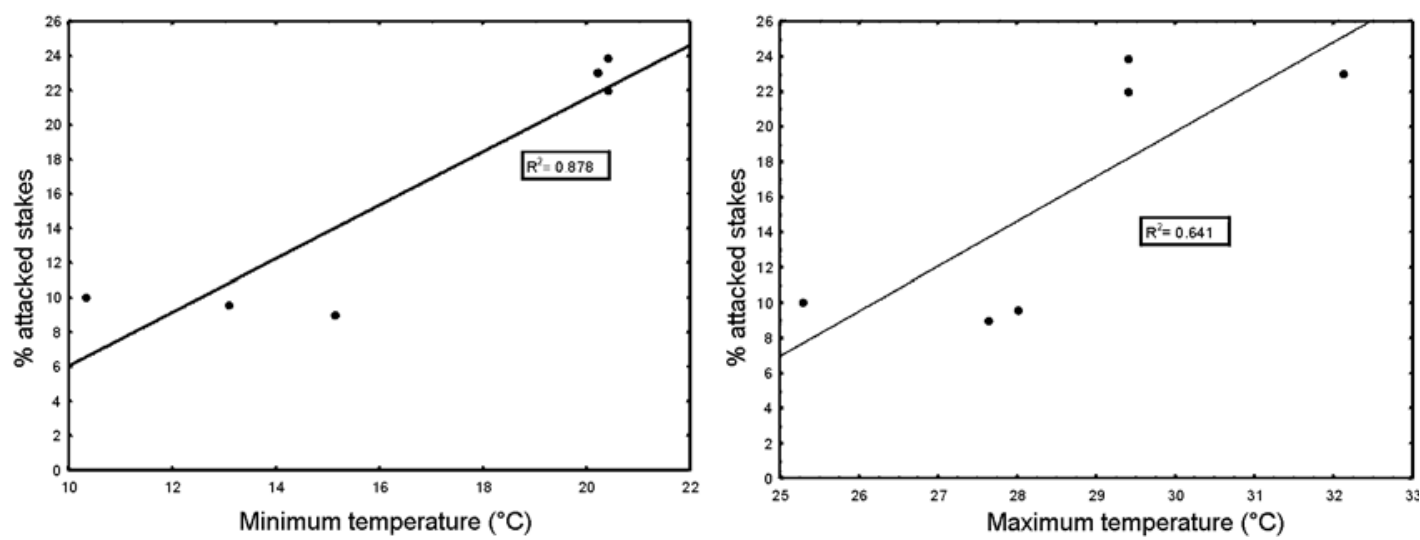

Fig. 2. The relationships between the percentage of stakes attacked and the maximum and minimum temperatures $\left({ }^{\circ} \mathrm{C}\right)$.

lation estimates of $C$. gestroi and H. tenuis are lower than those for other Coptotermes species, nevertheless, the colonies of $C$. gestroi and H. tenuis were larger than those of the Nearctic termites Reticulitermes virginicus and $R$. flavipes.

Both methods used to estimate the population sizes of $C$. gestroi and $H$. tenuis using triple-mark-recapture gave different results. In general, the mean Lincoln index estimates were lower than the weighted mean estimates for all the colonies studied. The inflated Lincoln index estimates obtained for other subterranean species (Table 3) may have resulted from very low recapture rates of marked individuals (less than 1\%). Lincoln index estimates are calculated for each mark-release-recapture and a low number of recaptured individuals at a single census, may increase the population estimates. Nevertheless, most of the studies using these methods do not give the number of marked individuals recaptured.

The low number recaptured could be due to some stained individuals loosing their marks. In this study the mark persisted, survival of marked individuals was close to $100 \%$ and only darkly stained individuals were used for the population estimates. Foraging behaviour in subterranean termites is a collective process, which minimizes energetic costs (Hedlund \& Henderson, 1999), and depends on either the size or quality of the food source (Waller \& La Fage, 1987). Moreover, age polyethism in the worker caste could also affect the number of individuals recaptured when additional medium and large workers are recruited for foraging tasks. This might also explain the absence of a correlation between the number of marked individuals and the total number of individuals recaptured at a monitoring station.

Violations of behavioural assumptions of mark-release methods have implications for the interpretation of the estimates of population size (Curtis \& Waller, 1997); however, foraging patterns of species of subterranean termites are almost identical and quantitative comparisons are usually performed among species of termites in most studies. In addition, mark-release provides information on territory size and fluctuations in demography, and thus can be used to improve the control and management techniques in both urban and rural landscapes ( $\mathrm{Su} \&$ Scheffrahn, 1996, 1998; Forschler \& Jenkins, 2000; Su, 2002).

Climatic factors are important regulators of foraging activity in termites in southeastern Brazil, where temperature and rainfall differ in summer and winter. The percentage of stakes attacked was positively related to the mean minimum temperatures recorded in summer and winter. In this region, differences in the mean minimum temperature between these seasons range from 12 to $14^{\circ} \mathrm{C}$. This is consistent with the results of Haagsma \& Rust (1995), who found that minimum temperature was the most important factor affecting activity in $R$.

TABLE 3. Published estimates of the foraging populations of subterranean termites, territory size $\left(\mathrm{m}^{2}\right)$, and maximum linear distance $(\mathrm{m})$ travelled by workers.

\begin{tabular}{cccccc}
\hline Species & Estimator method & Population & Territory & Distance & Reference \\
\hline \multirow{2}{*}{ Reticulitermes flavipes } & Weighted mean & $970-1453021$ & $266-1091$ & $48-79$ & $\begin{array}{c}\text { Forschler \& Townsend } \\
(1996) \text {; Grace et al. (1989) }\end{array}$ \\
& Lincoln Index & $1111-384615$ & & - & $\begin{array}{c}\text { Forschler \& Townsend } \\
(1996)\end{array}$ \\
W. virginicus & Weighted mean & $20109-156997$ & & - & Su \& Scheffrahn (1988) \\
Coptotermes formosanus & Weincoln Index & $18893-153945$ & - & Lee (2002) \\
C. travians & Weighted mean & $3846329-18834481$ & - & - & Evans et al. (1998) \\
C. lacteus & Lincoln Index & $11718537-33327481$ & & -115 & Sornnuwat et al. (1996) \\
& Weighted mean & $1127000-2750000$ & - & - & Costa-Leonardo (2002) \\
\hline
\end{tabular}


hesperus. However, environmental factors may have a different effect on the activity of the termites, as described for other subterranean species (Delaplane et al., 1991; Haagsma \& Rust, 1995). In the present study, wood consumption was similar in summer and winter, which suggests the existence of a compensation strategy in the foraging activities in both seasons, as described for $C$. formosanus (Waller \& La Fage, 1987). On the other hand, there is a trend that consumption differs between termite species; however, other factors such as population size, food availability or competition could influence this result.

In this study, stakes of Pinus sp. (low density wood) were more readily eaten than those of Eucalyptus sp. (high density wood). Field studies of wood consumption are scarce and information on termite food preferences is limited to laboratory experiments in which termites are offered a limited range of different food sources (Lenz, 1994). These studies indicate that C. formosanus prefers low density and moist wood or wood damaged by conspecifics (Delaplane \& La Fage, 1989). On the other hand, food choice experiments using Reticulitermes sp. indicate that this termite prefers woods that contain low quantities of tannin and terpenoids, which are toxic to insects (Ripa et al., 2002).

According to Delaplane \& La Fage (1987), once termite foragers chose a particular food source, they exploit it to the exclusion of all others. Moreover, termite feeding seems to be associated with the size of the food source (Waller, 1988; Lenz, 1994), as we found for C. gestroi and $H$. tenuis, in which foragers feed significantly more on the larger stakes. The low number of stakes attacked by termites in the foraging territories of field colonies of $C$. gestroi and $H$. tenuis may be due to the presence of alternative food sources, which were considerably larger than the stakes used in this study. However, other factors could have influenced wood consumption in these species, such as the tunnel construction pattern of the foragers, soil particle size and available water.

The results obtained for $C$. gestroi and $H$. tenuis did not show differences in the extent to which wooden stakes buried at different depths were attacked. Some termite species attack mainly stakes barely buried in the soil (Shahid \& Akhtar, 1989). Nevertheless, the difference in the soil depth at which they feed might be species specific or the stakes used in this study were too short.

Demographic patterns of $C$. gestroi and $H$. tenuis varied between colonies and species. Even though for subterranean termites some of the behavioral assumptions of mark-recapture methods are not met, this study showed that colonies of $C$. gestroi and $H$. tenuis are larger than those reported for Nearctic species. Even though, the foraging activity of these termites depended on the minimum temperature, wood consumption did not change between summer and winter. These results could indicate the presence of a compensation strategy in foraging, which is dependent on the minimum temperature. This information will be useful for improving the control of both species of termites. Nevertheless, further studies aimed at under- standing the searching patterns of these subterranean species are being conducted under controlled laboratory conditions.

ACKNOWLEDGEMENTS. This work was supported by FAPESP (Fundação de Amparo à Pesquisa no Estado de São Paulo), PhD grant 00/11451-3. We thank J. Rincones for reviewing the grammar and syntax of the English text and C. Mileo for drawing the diagrams. We also thank three anonymous reviewers for their suggestions.

\section{REFERENCES}

ARAujo R.L. 1958: Contribuição à biogeografia dos térmitas de São Paulo, Brasil (Insecta, Isoptera). Arq. Inst. Biol. 25: 185-217.

Begon M. 1979: Investigating Animal Abundance: CaptureRecapture for Biologist. University Park Press, Baltimore, $\mathrm{MD}, 97 \mathrm{pp}$

Costa-Leonardo A.M. 2002: Cupins-Praga: Morfologia, Biologia e Controle. Rio Claro, Sao Paulo, 128 pp.

Curtis A.D. \& Waller D.A. 1997: Problems with the interpretation of mark-release recapture data in subterranean termites (Isoptera: Rhinotermitidae). Sociobiology 30: 233-241.

Delaplane K.S. \& La Fage J.P. 1987: Variance in feeding on equivalent wood blocks by the Formosan subterranean termite in laboratory choice tests. Sociobiology 13: 227-233.

Delaplane K.S. \& La Fage J.P. 1989: Preference of the Formosan subterranean termite (Isoptera: Rhinotermitidae) for wood damaged by conspecifics. J. Econ. Entomol. 82: $1363-1366$.

Delaplane K.S., SaXton A.M. \& La Fage J.P. 1991: Foraging phenology of the Formosan subterranean termite (Isoptera: Rhinotermitidae) in Louisiana. Am. Midl. Nat. 125: 222-230.

Evans T.A., Lenz M. \& Gleeson P.V. 1998: Testing assumptions of mark-recapture protocols for estimating population size using Australian mound-building, subterranean termites. Ecol. Entomol. 23: 139-149.

Evans T.A., Lenz M. \& Gleeson P.V. 1999: Estimating population size and forager movement in a tropical subterranean termite (Isoptera: Rhinotermitidae). Environ. Entomol. 28: 823-830.

Forschler B.T. \& JeNKIns T.M. 2000: Subterranean termites in the urban landscape: understanding their social structure is the key to successfully implementing population management using bait technology. Urban Ecosyst. 4: 231-251.

Forschler B.T. \& Townsend M.L. 1996: Mark-releaserecapture estimates of Reticulitermes spp. (Isoptera: Rhinotermitidae) colony foraging populations from Georgia, U.S.A. Environ. Entomol. 25: 952-962.

Grace J.K., Abdallay A. \& Farr K.R. 1989: Eastern subterranean termite (Isoptera: Rhinotermitidae) foraging territories and populations in Toronto. Can. Entomol. 121: 551-556.

HaAgsma K.A. \& Rust M.K. 1995: Colony size estimates, foraging trends, and physiological characteristics of the Western subterranean termite (Isoptera: Rhinotermitidae). Environ. Entomol. 24: 1520-1528.

Hedlung J.C. \& Henderson G. 1999: Effect of available food size on search tunnel formation by the Formosan subterranean termite (Isoptera: Rhinotermitidae). J. Econ. Entomol. 92: 610-616.

JoNES S.C. 1990: Delineation of Heterotermes aureus (Isoptera: Rhinotermitidae) foraging territories in a Sonoran desert grassland. Environ. Entomol. 19: 1047-1054.

KirTon L.G. \& BRown V.K. 2003: The taxonomic status of pest species of Coptotermes in Southeast Asia: Resolving the 
paradox in the pest status of the termites, Coptotermes gestroi, C. havilandi, and C. travians (Isoptera: Rhinotermitidae). Sociobiology 42: 43-63.

LEE C.Y. 2002: Control of foraging colonies of subterranean termites, Coptotermes travians (Isoptera: Rhinotermitidae) in Malaysia using Hexaflumuron baits. Sociobiology 39: 411-416.

LENZ M. 1994: Food resources, colony growth and caste development in wood-feeding termites. In Hunt J.H. \& Nalepa C.A. (eds): Nourishment and Evolution in Insect Societies. Westview Press, Oxford, pp. 159-209.

NutTing W.L. \& Jones S.C. 1990: Methods for studying the ecology of subterranean termites. Sociobiology 17: 167-189.

Ripa R., Castro L., Su N.Y. \& Palma P. 2002: Laboratory estimate of wood consumption rates by Reticulitermes sp. (Isoptera: Rhinotermitidae) in Chile. Sociobiology 39: 285-290.

Shahid A.S. \& AKhtar M.S. 1989: Effect of volume and position of stakes on feeding by subterranean termites (Isoptera). Sociobiology 16: 99-108.

SoKal R.R. \& RohlF J. 1995: Biometry. W.H. Freeman, New York, $887 \mathrm{pp}$.

Sornnumat Y., Tsunoda K., Yoshimura T., Takahashi M. \& VongKaluANG C. 1996: Foraging population of Coptotermes gestroi (Isoptera: Rhinotermitidae). J. Econ. Entomol. 89: $1485-1490$.

Su N.-Y. 2002: Novel technologies for subterranean termite control. Sociobiology 40: 95-101.
Su N.-Y. \& Scheffrahn R.H. 1988: Foraging population and territory of the Formosan subterranean termite (Isoptera: Rhinotermitidae) in an urban environment. Sociobiology 14: 353-359.

Su N.-Y. \& SCHEFFRAHN R.H. 1996: A review of the evaluation criteria for bait-toxicant efficacy against field colonies of subterranean termites (Isoptera). Sociobiology 28: 521-530.

Su N.-Y. \& Scheffrahn R.H. 1998: A review of subterranean termite control practices and prospects for integrated pest management programmes. Integr. Pest Manag. Rev. 3: 1-13.

Su N.-Y., Ban P.M. \& Schefrrahn R.H. 2000: Control of Coptotermes havilandi (Isoptera: Rhinotermitidae) with Hexaflumuron baits and a sensor incorporated into a monitoring and bating program. J. Econ. Entomol. 93: 415-421.

Thorne B.L., Russek-Cohen E., Forschler B.T., Breisch N.L. \& Traniello J.F.A. 1996: Evaluation of mark-releaserecapture methods for estimating forager population size of subterranean termite (Isoptera: Rhinotermitidae) colonies. Environ. Entomol. 25: 938-951.

WALLER D.A. 1988: Host selection in subterranean termites: factors affecting choice (Isoptera: Rhinotermitidae). Sociobiology 14: 5-13.

WALler D.A. \& LA FAGE J.P. 1987: Seasonal patterns in foraging groups of Coptotermes formosanus (Rhinotermitidae). Sociobiology 13: 173-181.

Received October 29, 2004; revised and accepted July 7, 2005 